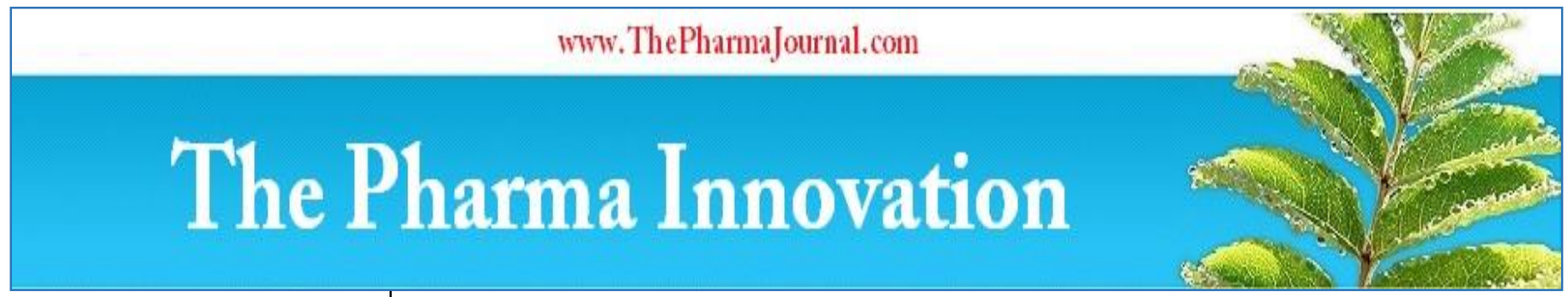

ISSN (E): 2277 - 7695

ISSN (P): 2349-8242

NAAS Rating: 5.23

TPI 2021; 10(5): 163-171

(C) $2021 \mathrm{TPI}$

www.thepharmajournal.com

Received: 07-03-2021

Accepted: 17-04-2021

\section{Shivani Sharma}

Lovely Faculty of Technology

and Sciences, Lovely

Professional University,

Phagwara, Punjab, India

\section{Dr. Anjan Borah}

Lovely Faculty of Technology

and Sciences, Lovely

Professional University,

Phagwara, Punjab, India
Corresponding Author: Dr. Anjan Borah

Lovely Faculty of Technology

and Sciences, Lovely

Professional University,

Phagwara, Punjab, India

\title{
Bioactive compounds present in different parts of Guava and their significance: A review
}

\section{Shivani Sharma and Dr. Anjan Borah}

DOI: $\underline{\text { https://doi.org/10.22271/tpi.2021.v10.i5c.6193 }}$

\begin{abstract}
Guava (Psidium guajava L.) is a tropical and subtropical fruit crop that is commonly used in food and traditional medicine all over the world. It is a member of the Myrtaceae family. Tannins, flavonoid: quercetin, pentacyclic triterpenoid: guajanoic acid, saponins, carotenoids, lectins, leucocyanidin, uvaol, amritoside, betasitosterol, ellagic acid, oleanolic acid, triterpenes, and ursolic acid are some of the essential phytoconstituents. Guava can be eaten raw or refined into juice, pulp, jam, jelly, nectar, powder, tea, and other items. The guava plant parts are utilized for the improvement of variety industrial and medicinal products. Antiviral, anti-inflammatory, antidiabetic and anti-mutagenic factors are all found in guava. Guava extract has antinociceptive properties and can help with liver inflammation and serum development.
\end{abstract}

Keywords: Guava, bioactive compounds, antioxidants

\section{Introduction}

Guava (Psidium guajava) is an evergreen bush or little tree in the family Myrtaceae developed for its consumable natural products. Guava (Psidium guajava Linn.) is a fruit that is wellknown for its culinary and nutritious qualities all over the world (Etim et al, 2020) ${ }^{[1]}$. The fruit is also as "The fruit of the poor guy" or "Tropical apple". Guava is commonly grown in common tropical and subtropical regions (Adhau and Salvi, 2014) ${ }^{[2]}$. Guava (Psidium guajava Linn.) is a tropical American fruit that was first introduced to India in the early seventeenth century. Guava is grown in India, Mexico, Brazil, Cuba, Venezuela, Australia, South Africa, Thailand, Malaysia, Indonesia, China, Sri Lanka, the Philippines, Bangladesh, Myanmar, the Dominican Republic, the United States, and Haiti (Mitra et al, 2012) ${ }^{[3]}$. Guava stands fifth in production among India's most important fruit crops and can be grown throughout the country. Important guava growing states in the country are Uttar Pradesh, Madhya Pradesh, Maharashtra and Bihar, Allahabad district of Uttar Pradesh is very popular for growing the excellent quality of guava fruits in the world(Jolhe et al, 2020) ${ }^{[4]}$. Guava is grown accros the country which is ( 0.25 million hectares) with an annual yield of 4.08 million tons respectively. Depending on the species, guava fruits are typically 4 to 12 centimetres (1.6 to 4.7 in) long, round or oval. The fruit is initially green in color, but as it ripens, it turns yellow (Kafle et al, 2018) ${ }^{[5]}$. The fruit contains approximately 80 percent moisture and 20 percent dry matter including 1 percent ash, 0.7 per cent fat and 1.5 percent protein (Upadhyay et al, 2019) ${ }^{[6]}$.

Guava fruit is commonly eaten fresh as a dessert fruit or processed as puree, juice, concentrate, jam, jelly, cheese, toffee, fruit flakes, squash, syrup, nectar, powder, wine, vinegar, ready-toeat snacks, beverages, and dehydrated canned products (Sinha and Mishra, 2017) ${ }^{[7]}$. The root, bark, leaves, and fruit of the plant have been reported to have pharmacological properties (Seshadri et al, 2020) ${ }^{[8]}$ and are used to cure a variety of ailments. malaria, gastroenteritis, spewing, looseness of the bowels, diarrhea, wounds, ulcers, toothache, sore throat, swollen gums, and a host of other symptoms have also been handled with various sections of the plants throughout herbal medicine (Biswas et al, 2013) [9]. This plant has also been used to treat lifethreatening illnesses including diabetes, hypertension, and obesity. Guava fruit comes in two varieties of white and pink interior Interspersed with little hard seeds. White guava has a sweeter flavor and is more widely cultivated, while pink guava is considered a delicacy. The fruits are circular to ovoid, fleshy, yellow, and around $5 \mathrm{~cm}$ in diameter, with a pink or white edible mesocarp containing small round seeds. 
Guava seeds make up between 6-12 percent of the total weight of the fruit. The seeds are round in shape and pale yellowish brown in color, with 16 percent oil, 7.6 percent protein, and 61.4 percent crude fiber content. Guava seeds, have the ability to become a source of oil that can be used in food products and as a dietary supplement (Raihana et al, 2015) ${ }^{[10]}$. The leaves are opposite, oblong, three to seven inches long, and have prominent veins on the underside. Guava leaf is widely used to treat diarrhea, gastroenteritis, and other digestive issues, while the fruit of the guava has been used to raise platelets in dengue fever patients (Laily et $a l, 2015)^{[11]}$. The guava bark is thin and has green patches on it. It is incredibly easy to dispense with it in long straps. It contains a significant volume of antimicrobial and antibacterial substances (Rahim et al, 2010) ${ }^{[12]}$.

Guava is a very rich source of ascorbic acid (vitamin C) and contains other nutraceutical components, including vitamin $\mathrm{A}$ (beta-carotene), vitamin B1 (thiamine), (B2) riboflavin, niacin and pantothenic acid (Vijaya Anand et al, 2020) ${ }^{[13]}$. Moreover, it additionally contains a considerable measure of phosphorous, calcium, iron, potassium, and sodium. The major ingredients of guava are citric acid and acetic acid (Palachum et al, 2020) ${ }^{[14]}$. Guava's dietary importance is enhanced by the presence of antioxidant pigments such as carotenoids and polyphenols. These various bioactive nutrients play a significant role in traditional therapies for various lifestyle problems, such as diabetes (type 2) and obesity (Upadhyay et al, 2019) ${ }^{[15]}$. $\alpha$-pinene, $\beta$-pinene, limonene, menthol, $\beta$-sitosterol, cineol, quercetin are bioactive compounds with different pharmacological activity (Ngbolua, 2018) ${ }^{[16] .}$

\section{Cultivation of guava}

Guava is raised in both tropical and subtropical regions up to $1500 \mathrm{~m}$. above mean sea level. It tolerates high temperatures and drought conditions in northern India during the summers

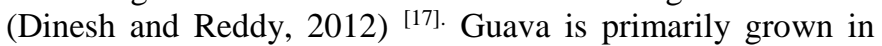
the tropics and can withstand temperatures of $15-45{ }^{\circ} \mathrm{C}(59-$ $113^{\circ} \mathrm{F}$ ) (Singh, 2011) ${ }^{[18]}$. Guava grows optimally between 23 and $28^{\circ} \mathrm{C}\left(73-82^{\circ} \mathrm{F}\right)$ but established trees can tolerate short periods at -3 to $-2^{\circ} \mathrm{C}\left(27-28^{\circ} \mathrm{F}\right)$ although temperatures below $15^{\circ} \mathrm{C}\left(60^{\circ} \mathrm{F}\right)$ may cause the tree to stop producing fruit. It is, however, vulnerable to heavy frost, which can destroy young plants. During the rainy season (July - September), an annual rainfall of about $100 \mathrm{~cm}$ is adequate. The quality of the fruits is harmed by rain during the harvesting season. Guava can grow in a variety of soils, including sandy and rocky soils, as well as loams, preferring a $\mathrm{pH}$ of $4.5-7$ but tolerating alkaline soils up to $\mathrm{pH}$ 8.5. (Birdi et al, 2020) [19]. Guava is more drought tolerant than most tropical fruits, and it can survive long periods of drought by ceasing vegetative development before the weather improves. Guavas of high quality are grown in river basins. Water logging is a problem for the crop (Sehrawat et al, 2014) ${ }^{[20] . ~ D u r i n g ~ t h e ~ r a i n y ~ s e a s o n, ~ p l a n t i n g ~}$ takes place. The months of June and July are suitable for planting the layers and seedlings. India is the top producer of guava in the world and approximately 200640 hectare agricultural land has been used for Guava cultivation. Different cultivars of guava has been grown across the country and reported productivity of $15.3 \mathrm{MT} / \mathrm{Ha}$ respectively. UP is leading in guava production having 928.44 tonnes of produce in 2017-2018. Top ten guava producing states and varieties grown therein have been shown in Table no 1.

\section{Taxonomy of guava}

The guava plant (Psidium guajava L.) belongs to the Myrtaceae family. Psidium guajava is the most important fruit of the genus Psidium, which contains around 150 species. Guava is thought to have originated from an area extending from southern Mexico to or through Central America. Singh, 2011) ${ }^{[21]}$. Guava is widely known and cultivated throughout the world (Paull and Duarte, 2012) ${ }^{[22] .}$

$\begin{array}{ll}\text { Kingdom: } & \text { Plantae } \\ \text { Order: } & \text { Myrtales } \\ \text { Family: } & \text { Myrtaceae } \\ \text { Subfamily: } & \text { Myrtoideae } \\ \text { Genus: } & \text { Psidium } \\ \text { Species: } & \text { Guajava } \\ \text { Binomial name: } & \text { Psidium guajava } \text { Linn. }\end{array}$

\section{Nutritional value of guava}

This popular fruit is a source of nutrients. The fruit is a good source of carbohydrates, proteins, fats, minerals, and other nutrients, and thus may help reduce the risk of malnutrition (Youssef and Ibrahim, 2016) [23]. According to the USDA's Food Data Central, guava is a strong source of protein $(2.3 \%)$, carbohydrates $(12.16 \%)$, and dietary fiber $(4.8 \%)$, among other popular fruits. Guava has been stated to be a good source of calcium, with $17.63 \mathrm{mg}$ per $100 \mathrm{~g}$. In addition, Guava is an excellent source of ascorbic acid, i.e. 241,86 $\mathrm{mg} / 100 \mathrm{~g}$, which, together with various fruits, makes it a promising source of discovery and added value in food

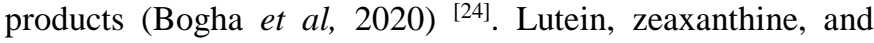
lycopene are abundant in guava. It is rich in flavonoids, fructose sugar, and carotenoids (Das, 2011) ${ }^{[25]}$. Minerals such as calcium, phosphorus, iron, and vitamins like niacin, pantothenic acid, thiamin, riboflavin, vitamin A, and vitamin E are abundant in fruit (Reddy, 2017) ${ }^{[26]}$. Guava contains both polyphenolic compounds and carotenoids, which provide the fruit with antioxidant pigments, making it one of the most antioxidant-rich fruits (Omayio et al, 2019) ${ }^{[27] . ~ E s s e n t i a l ~ o i l s, ~}$ phenols, triterpenes, saponins, flavonoids, lectins, fiber, and pectin, as well as fatty acids, are all present in guavas. Caffeic, coumaric, ferulic, cinnamic, ellagic, and rosmarinic acids are among the polyphenol and glycoside esters found in guava fruit. (Medina and Herrero, 2016) ${ }^{[28]}$. Flavonoids such as myricetin, naringenin, epicatechin, quercetin, rutin and apigenin have been found. (Vijaya Anand et al, 2020) ${ }^{[29]}$. The major components in fruit are $\alpha$-Pinene, $\beta$-caryophyllene, (Z)3 -hexenal, and $\alpha$-humulene. Carbonyls and esters such as 3hydroxy-2butanone, benzaldehyde, ethyl hexanoate, (Z)-3hexenyl acetate, hexyl butanoate, and ethyl octanoate are only contained throughout the fruit (Lee et al, 2011) [30]. Guava leaves contain variety of chemical components for example, $\alpha$-pinene, $\beta$-pinene, limonene, menthol, caryophyllene, $\beta$ bisabolene, farnesene, humulene, selinene, cardinene and curcumene, mallic acids, $\beta$-copanene, $\beta$-sitosterol, cineol, quercetin, tannin, guajavolide and guavenoic acid, resin, triterpernes, such as oleanolic acid, triterpenoids, prenol, dihydrobenzophenanthridine, and cryptonine. flavonone-2, 2'ene (Thome et al, 2019) ${ }^{[31]}$. In Guava seed Presence of bioactive components such as polyphenols, tocopherols and phytosterols in these fruit seed oils makes them highly desirable due to their beneficial effects on human body. Guava seeds had a protein content of 9.73 percent dry matter, with 15 amino acids, 67 percent of which were arginine, glutamic acid, aspartic acid, glycine, and leucine. The main 
fatty acids were linoleic (60.0 percent), palmitic (14.8 percent), oleic (12.5 percent), stearic (9.08 percent), and arachidic (1.31 percent). Being a rich source of linoleic acid, it can be used to supplement food products deficient in omega-6 essential fatty acid. guava seed oil is a good source of palmitic acid and stearic acid and apart from that siginificant amount of mono unsaturated fatty acid(MUFA) and poly unsaturated fatty acid (PUFA) (Kapoor et al, 2020) [32]. Proteins, oils, phenolic, flavonol glycoside, starch, flavonoid compounds, quercetin-3-O-D-(2"Ogalloyglucoside)-4'-O-vinylpropionate are all contained in guava seed (Molla and Azene, 2011) ${ }^{[33]}$. Psidium guajava twigs contain calcium, magnesium, phosphorus, potassium and sodium. Concentrations of fluoride, copper, iron, zinc, manganese, lead and also contains flavonoid, sesquiterpene alcohols and triterpene acids (Ngbolua, 2018) [34]. The bark contains 12-30 per cent tannin and one of the sources states that it contains 27.4 per cent tannin or polyphenols, resin and calcium oxalate crystals. Tannin can be found in roots as well. Roots also include leukocyanidins, gallic acid, and sterols (Naseer et al, 2018) ${ }^{[35]}$.

\section{Utilization of different part of guava}

Guava is used to make a variety of processed items, including drinks, syrup, ice cream, jams, jellies, toffee, juice, and dehydrated and canned products. Additionally different parts of guava being utilized for different pharmacological applications.

\section{Food utilization}

The guava has incredible potential for broad business use because of its simplicity of development, high nutrient content, and processing in a variety of consumer products (Kocher, 2011) ${ }^{[36]}$. There are a variety of products that can be made from guava processing including guava jam, juice, pulp, jellies, chocolate, wine and guava powder (generally utilized in the preparing of yogurt) and spray soluble guava extracts containing high antioxidants concentrations (Kadam et al, 2012) ${ }^{[37]}$.

Guava Jams and Jellies: Jam is a semi-solid mixture obtained by cooking a fruit soft tissue with sugar. Jam is an in-between moisture food prepared by boiling fruit pulp with sugar (sucrose), pectin, acid and other ingredients (additive, coloring and flavoring materials) to a rationally thick evenness, firm enough to hold the fruit tissues in position (Rahman et al, 2018) ${ }^{[38]}$. The jam could be between 65 and 68 degree Brix after which it is hot filled into cleaned and disinfected glass containers.

Guava jelly is made from slightly ripe guava fruits. Jelly is a semi-solid product that is prepared by boiling clear strained fruit extracts free of pulp after adding the required amount of sugar, citric acid and pectin. It should have a total soluble solids content of at least 65 percent and a fruit portion of at least 45 percent (Jolhe et al, 2020) ${ }^{[39]}$. The fruit is sliced into little pieces and cooked for around 45 minutes at low temperatures with utilizing similar measure of water and the juice extricated by filtration utilizing sifters or muslin cloth (Kuchi et al, 2014) ${ }^{[40]}$. Sugars are added to the extracted juice until it is boiled to $105^{\circ} \mathrm{C}$ or a layer is formed by cooling a little segment in a spoon. The measure of sugar utilized differs relying upon the pectin content of the extracted juices, going from $0.5 \mathrm{~kg}$ sugar $/ \mathrm{kg}$ juice to $0.75 \mathrm{~kg}$ sugar $/ \mathrm{kg}$ juice for pectin rich juice and low-pectin juice respectively. After that, hot filling into clean and sterlized containers (SWER et al, 2019) ${ }^{[41]}$.

Guava leathers: Guava leather is prepared by dehydrating the purée of fruit into a leather sheet. Leathers can be eaten as a confection or cooked to make a sauce. In the tropics, there is a scarcity of knowledge on the chemical and organoleptic properties of guava leathers. Guava leather has a higher protein and fat content. This was also noted in ash content with pawpaw leather (2.67 per cent) and guava leather $(2.87$ percent) (Kanwal et al, 2016) ${ }^{[42] .}$

Guava Shrikhand: The current consumer preference for reduced or low-fat products that help to reduce the risk of chronic degenerative diseases has prompted the production of probiotic low-fat foods such as shrikhand, a semisolid light, sweetish sour fermented dairy product. In Gujarat, Maharashtra, and Karnataka, it is a famous delicacy. The procedure for making shrikhand began with heating skim milk, cooling it at $30{ }^{\circ} \mathrm{C}$ in a batch pasteurizer, adding lactic acid bacteria (LAB) starter culture, and thoroughly mixing it with a mixer. The temperature of the pre-sterilized storage vat was kept at $37{ }^{\circ} \mathrm{C}$ during the incubation period, which lasted between 8 to 12 hours. After the curd was properly set, the contents were transferred to another vessel through a clean, moist muslin cloth. Sugar and guava powder have been added to this chakka and have been thoroughly mixed either manually or mechanically to a homogeneous consistency. It is usually packaged in polystyrene cups and stored under refrigerated conditions (Kumar, 2011) ${ }^{[43]}$.

Guava Juice and Nectars: The Fresh fruits or the pulp of the guava are used to produce guava juice. Juice is separated by squeezing the guava fruit with hydraulic filterl press or from the pulp after dilution with water and resulting filtration. The juice is generally not clear and requires the use of pectic enzymes to make it smoother and easier to clean. Studies by Imungi showed that the ideal conditions for removing guava juice utilizing proteolytic enzymes from Kenyan guava were $400 \mathrm{ppm}$ compound at a temperature of 45-50 degree $\mathrm{C}$ for an hour and a half (90 minutes).

Nectars- Water is added to guava pulp or fresh juice to produce nectar. Allowed added substances or sweetners, just as sugar could conceivably be added yet the items should have at least $8.5^{\circ}$ Brix, 25.0 percent of the guava puree or juice and acidity 0.15 percent at a $\mathrm{pH}$ of $3.4-4.8$ (Omayio et al, 2019) ${ }^{[44]}$.

Guava wine: The wine made from guava (Psidium guajava L.) is the result of anaerobic yeast fermentation, in which the sugars are converted to alcohol and carbon dioxide (Sevda and Rodrigues, 2011) ${ }^{[45]}$.

Guava leaf tea: The leaf of Psidium guajava was extracted with hot water and yielded 14 percent guava leaf extract. In a summary, $100 \mathrm{~g}$ of dried leaves were mixed with $2 \mathrm{~L}$ of distilled water (DW) and decocted at $80{ }^{\circ} \mathrm{C}$ for 30 minutes. The extracted solution was freeze dried after filtering through four layers of gauze to remove leaves (Kaneko et al, 2013) [46].

Guava leaf powder: The guava leaves were collected and manually shredded into small pieces. Subsequently, the biomaterial was washed a few times using ordinary tap water 
followed by a single wash with pure distilled water to make it free from dust and undesired soluble contaminants. The wet material was allowed to sit in a clean and dry place to allow free water to evaporate from the surface and thereafter was placed in an electric oven at $50{ }^{\circ} \mathrm{C}$ for $24 \mathrm{~h}$. The dried guava biomass was kept in desiccator while cooling, crushed into powdered form and stored in moisture-free conditions until further use in experimentations (Ponnuchamy et al, 2019) ${ }^{[47] .}$

Guava seed powder: Firstly collection of seeds and seeds were dried in an air circulation oven (Tecnal, model TE-394 /L) at $60^{\circ} \mathrm{C}$ for approximately 16 hours. After dehydration, the seeds were crushed using a domestic blender (Walita) and the powder obtained. The powder was packaged in lidded polyethylene containers (Uchôa-thomaz et al, 2014) ${ }^{[48]}$.

\section{Guava seed powder fortified biscuits (GSPFB)}

With the help of response surface methodology (RSM), the level of guava seed powder, wheat flour and sugar was optimized. $17.65 \mathrm{~g}$ of guava seed powder, $62 \mathrm{~g}$ of wheat flour and $20 \mathrm{~g}$ of sugar were mixed. Butter $(25 \mathrm{~g})$, baking powder $(1 \mathrm{~g})$ and vanilla flavour $(2 \mathrm{ml})$ were also used. The oven was pre-heated to $180{ }^{\circ} \mathrm{C}$. The dough was then rolled on a platform and cut into round shape. Cut biscuit dough were then lined upon food grade steel mesh on an oven tray and baked in the oven at $180{ }^{\circ} \mathrm{C}$ for $25 \mathrm{~min}$ and cooled for $30 \mathrm{~min}$ at ambient temperature. Control samples were prepared without any addition of Guava seed powder. Biscuits of each formulation were made in triplicate. The process adopted for biscuit manufacture was as per the method elaborated by the AACC (2000). The biscuits were cooled for $30 \mathrm{~min}$ and then packed in Low density polyethylene pouches and sealed until further analysis (MAURYA and PANDEY) ${ }^{[49]}$.

Guava pomace: Guava pomace is a representation of preparing waste delivered after the production process, and it can represent up to $15 \%$ of the first natural fruit (Denny et al, 2013) 50. To get juice, Guava fruits were utilized. A cabinet tray dryer was utilized for drying guava pomace, which could correctly control the ideal drying temperature somewhere in the range of 20 and $150{ }^{\circ} \mathrm{C}$. The guava pomace, high in moisture content, ana dry at a temperature of $65^{\circ} \mathrm{C}$ as proposed by previous studies for drying carrot pomace. (Tangirala et al, 2012) ${ }^{[51]}$.

\section{Pharmacological utilization}

The use of guava in restorative practices was considered to be a few different Specialists in various diseases and has demonstrated the potential for the treatment of most diseases worldwide. Guava has been shown to be effective in the treatment of these diseases in ethno pharmacological assessments, research centres, and clinical preliminary studies. In addition, harmful quality evaluations of the roots, bark, leaves, natural items, blossoms and seeds of the plant have been viewed as safe for therapeutic purposes, both for oral and effective use, at whatever point controlled in blends and improvement structures (Gupta et al, 2020) ${ }^{[52]}$.

\section{Antioxidant activity}

Recent findings have shown that Psidium guajava is an important source of phytochemical antioxidants. Guava is a very good antioxidant and a rich source of vitamin C. Guava has antioxidant properties that are attributed to the polyphenols found in its leaves Guava leaf extracts and essential oil from the stem and bark will scavenge free hydrogen peroxide, superoxide anion radicals, and inhibit the development of hydroxyl radicals (Fasola et al, 2011) ${ }^{[53]}$ : (Vyas et a., 2010) ${ }^{[54]}$. The antioxidant properties of guava can be due to quercetin, carotenoids, vitamin $\mathrm{C}$, and polyphenols (Dakappa et al, 2013) ${ }^{[55]}$.

Quercetin, quercetin-3-O-glucopyranoside and morin may be extracted from the leaves. Antioxidant activity can be seen in these compounds. Quercetin has anti-oxidant properties. It is thought to be the most active and powerful antioxidant found in guava leaves (Soman et al, 2010) [56]; (Nantitanon et al, 2012) ${ }^{[57]}$.

\section{Anti-diabetic}

Blood glucose levels have been found to Psidium guajava. Guava fruit extract has been shown to help diabetes patients lose weight and control their blood sugar levels. Guava fruit extract was given at portions of 125 and $250 \mathrm{mg} / \mathrm{kg}$ to STZincited diabetics. Guava Fruit Extract reduces the depletion of insulin-positive beta cells and insulin release by protecting pancreatic tissues, including islet beta cells, from oxidation. (Huang et al, 2011) ${ }^{[58]}$. Quercetin, kaempferol, myricetin had inhibitory effects on sucrose, maltase, and $\alpha$-amylase (Wang et al, 2010) ${ }^{[59]}$.

\section{Anti-inflammatory activity}

Germ contamination and thymus production have been shown to be blocked by guava extract in ethyl acetate. It has the potential to serve as an antiviral agent. It has the ability to improve mRNA expression. Guava may alter the work of the heme oxygenase- 1 protein. Because of this, it can be used as an anti-inflammatory agent for the skin. The lipopolysaccharide that develops nitric oxide is inhibited by guava extract in ethanol. The outflow of E2 is inhibited. In this way, it serves as an anti-inflammatory agent (Jang et al, 2014) ${ }^{[60]}$.

\section{Anticancer effect}

A few examinations have shown that therapeutic plants of Psidium guajava effectsly affect human epidermal carcinoma and murine leukemia cells. The decrease measure, the LDH discharge examine, and the colony forming assay all revealed that the GBA was extremely cytotoxic. The concentrate showed inhibited of HT-29 cell development at $250 \mu \mathrm{g} / \mathrm{ml}$. branch extract displayed apoptotic impacts in HT-29 cells, including chromatin condensation and sharking. It causes cytotoxicity and raises the sub-G1 phase of HT-29 cells. (Lee and Park, 2010) ${ }^{[61]}$.

\section{Antiviral Activity}

Antiviral movement of guava extracts was resolved against development of A/Narita/1/2009 (amantadine-safe pandemic strain 2009) with an IC50 of 0.05 percent and development of A/Yamaguchi/20/06 (touchy strain) and A/Kitakyushu/10/06 (oseltamivir-safe strain). The development of these strains has been firmly hindered by guava extracts. Guava tea has been shown to be effective against flu infection and has additionally been appeared to build up viral tolerance in the body (Sriwilaijaroen et al, 2012) ${ }^{[62]}$.

\section{Antidiarrhoeal effect}

Quercetin and quercetin-3-arabinoside, obtained from the buds and leaves of Psidium guajava L. at concen. of 1.6 $\mu \mathrm{g} / \mathrm{ml}$, showed a morphine-like hindrance of the arrival of 
acetylcholine in the coxially prompted ileum followed by an underlying ascent in muscle tone followed by a consistent decline. Methanol extract from leaves $(8 \mu \mathrm{g} / \mathrm{ml})$ of Psidium guajava showed activity against simian (SA-11) rotavirus by 93.8 percent hindrance. Furthermore, guava galactose- lectin has been appeared to tie to Escherichia coli (a natural cause of diarrhea), hinder its bond to the intestinal wall, and accordingly avoid diarrheal inflammation. (Gupta et al. 2011) [63].

\section{Immunomodulatory activity}

Psidium guajava leaf extract showed immunomodulatory actitvity. Decoction of guava leaves has been shown to activate macrophages to destroy E. coli strain (heat stable toxin producer) using murine monocyte cell line, J774 (Birdi et al, 2014) ${ }^{64}$. Ethyl acetate fraction of guava leaves has been shown to suppress COX2 expression, cytokine secretion, degranulation, and FceRI-mediated signaling in antigenstimulated mast cells. A flavonoid fraction of guava leaf extract has been shown to control the activation of the nuclear factor $\mathrm{KB}$ in the in-vitro model system using Labeo rohita head renal macrophages (Daswani et al, 2017) ${ }^{[65] .}$

\section{Antiparasitic Activity}

Antiparasitic drug are utilized to treat irresistible infections brought about by ectoparasites, protozoa, parasitic fungi, and helminths, among other things. Guava leaf essential oil worked well in an in vitro antiparasitic experiment as a host for Toxoplasma gondii. Guava leaf essential oil's conceivable restorative activity may have prompted the in vitro reduction of free extremists associated with toxoplasmosis pathology (Lee et al, 2013) ${ }^{[66]}$.

\section{Wound healer}

The gingival, periodontal ligament fibers are composed of collagen. Fibroblasts are the most common cell type found in periodontium connective tissue. Vitamin $\mathrm{C}$ is required to maintain the periodontium's overall integrity (Ravi and Divyashree, 2014) ${ }^{[67]}$. Guava is rich in vitamin C (ascorbic acid). Ascorbic acid can regulate the statement of procollagen gene prompting collagen arrangement, changing the fibroblast separation through its consequences for extracellular matrix. The decoction of root bark is prescribed as a mouthwash for sore gums, and the decoction of leaves as an efficient gargle for swollen, bleeding gums (mittal et al, 2010) ${ }^{[68]}$.

\section{Antibacterial}

Guava extracts show antibacterial action against both Grampositive and Gram- negative bacteria. In vitro testing revealed that an aqueous mixture and a water-soluble methanol extract from guava leaves and bark had strong antibacterial efficacy against multidrug-resistant Vibrio cholera (Shu et al, 2011) [69].

\section{Guava for Cold and Cough}

Guava leaves have been shown to be beneficial in the treatment of colds and coughs. Guava is high in ascorbic acid and iron, which helps to relieve lung inflammation and mucous production while also keeping the respiratory tract free of pathogens. Fruit, especially raw fruit, or a decoction made from tender immature leaves, is extremely beneficial in the treatment of colds and coughs. Because of its astringent properties, it acts by disintegrating mucus polymers, loosening cough and reducing more mucus intake, keeping the respiratory tract, mouth, and lungs free of bacteria, and inhibiting current microbial behavior. Guava has a high concentration of vitamin $\mathrm{C}$, and has been shown to be very helpful in treating colds and coughs caused by bacteria or viruses. In many Indian villages, roasted ripe guava is used as a home remedy for severe cases of cough, cold, and congestion. Another study found that a hydro extract of Psidium guajava leaves significantly reduced coughing frequency caused by capsaicin aerosol within 15 minutes of administration when compared to a control (Kafle et al, 2018) [70].

\section{Hematological activity}

The methanolic extract of Psidium guajava bark can be used as a blood booster in anemic patients or as a prophylactic purpose. As a result, it is suggested that a concentration of $200 \mathrm{mg} / \mathrm{kg}$ could be sufficient to stimulate the necessary haemopoiesis. While the exact process by which the extract facilitated the rise in these hematological indices was not determined in this research, it is concluded that this behavior was a direct result of the extract on the haematopoietic systems (Fasola et al, 2012) ${ }^{[71]}$.

Table 1: Indian States according to decreasing order of guava production and varieties cultivated therein (APEDA2017)

\begin{tabular}{|c|c|c|c|}
\hline Sr. no. & States & Production (tonnes) & Varieties grown \\
\hline 1 & Uttar Pradesh & 928.44 & $\begin{array}{c}\text { L-49, Allahabad Safeda, Lucknow Safeda, Apple Colour, Chittidar, Red Fleshed, } \\
\text { Allahabad Surkha, Sardar, Mirzapuri Seedless, CISH-G-1, CISH-G-2, CISH-G-3 }\end{array}$ \\
\hline 2 & Madhya Pradesh & 686.70 & L-49, Allahabad safeda, Gwalior-27, Hafshi, Seedless Chittidar \\
\hline 3 & Bihar & 427.61 & Allahabad Safeda, Apple Colour, Chittidar, Hafshi, Harijha, Sardar, Selection-8 \\
\hline 4 & Andhra Pradesh & 229.78 & $\begin{array}{c}\text { Allahabad safeda, Lucknow 49, Anakapalli, Banarasi, Chittidar, Hafshi, Sardar, Smooth } \\
\text { Green, Safed Jam, Arka Mridula }\end{array}$ \\
\hline 5 & West Bengal & 215.20 & $\begin{array}{c}\text { L-49, Allahabad Safeda, Dudhe Khaja, Gole Khaja, Kabli, Baruipur, Chittidar, Harijha, } \\
\text { Sardar }\end{array}$ \\
\hline 6 & Chattisgarh & 197.18 & Lucknow 49', 'Allahabadi Safeda' and 'lalit' \\
\hline 7 & Punjab & 195.60 & $\begin{array}{c}\text { Punjab Pink, Allahbad Safeda, Arka Amulya, Sardar, Punjab Safeda, Punjab Kiran, } \\
\text { Shweta, Nigiski, Punjab Soft, Allahabad Surkha, Apple guava, Chittidar }\end{array}$ \\
\hline 8 & Gujarat & 169.57 & Nagpur seedless, Dharwar, Dholka, Kothrud, L-24, L-49, Nasik, Sindh \\
\hline 9 & Tamil Nadu & 155.06 & Anakapalli, Banarasi, Bangalore, Chittidar, Hafshi, Nagpur Seedless, Smooth Green \\
\hline 10 & Karnataka & 140.23 & Allahabad Safeda, L-49, Araka Mridula, Araka Amulya, Bangalore, Dharwar \\
\hline
\end{tabular}

Table 2: food utilization of different parts of guava

\begin{tabular}{|c|c|c|c|}
\hline Sr. no & Parts of guava & Utilization & refernces \\
\hline 1 & Fruit & Jam & Rahman et al, 2018 $^{[38]}$ \\
\hline 2 & Fruit & Jellies & Jolhe et al, 2020; Kuchi et al, 2014; SWER et al, 2019 ${ }^{[39-41]}$ \\
\hline
\end{tabular}




\begin{tabular}{|c|c|c|c|}
\hline 3 & Fruit & Wine & Sevda and Rodrigues, $2011^{[45]}$ \\
\hline 4 & Fruit & Leathers & Kanwal et al, $2016^{[42]}$ \\
\hline 5 & Leaf & Tea & Kaneko et al, $2013^{[46]}$ \\
\hline 6 & Leaf & Powder & Ponnuchamy et al, $2019^{[47]}$ \\
\hline 7 & Seed & Powder & Uchôa-thomaz et al, $2014^{[48]}$ \\
\hline 8 & Guava Seed Powder Fortified Biscuits (GSPFB) & Powder & MAURYA and PANDEY ${ }^{[49]}$ \\
\hline 9 & Fruit & Juice & Omayio et al, $2019^{[44]}$ \\
\hline 10 & Fruit & Nectars & Omayio et al, $2019^{[44]}$ \\
\hline 11 & Guava pomace & & Tangirala et al, $2012^{[51]}$ \\
\hline
\end{tabular}

Table 3: pharmacological utilization of different parts of guava

\begin{tabular}{|c|c|c|c|}
\hline Sr. no & Parts of guava & utilization & refernces \\
\hline 1 & $\begin{array}{l}\text { Leaf } \\
\text { Leaf }\end{array}$ & Antioxidant activity & $\begin{array}{l}\text { Fasola,et al, 2011); (Vyas et al, } 2010^{[53 ; 54]} \\
\text { Soman } \text { et al, 2010); (Nantitanon et al, } 2012^{[56 ; 57]}\end{array}$ \\
\hline 2 & Fruit & Anti-diabetic & Huang et al, 2011 $1^{[58]}$ \\
\hline 3 & Guava skin & Anti-inflammatory activity & Jang et al, $2014^{[60,59]}$ \\
\hline 4 & buds & Antidiarrhoeal Effect & Gupta et al, $2011^{[63]}$ \\
\hline 5 & Leaf & Immunomodulatory activity & Birdi et al, 2014; Daswani et al, $2017^{[64,65]}$ \\
\hline 6 & Leaf & Antiparasitic Activity & Lee et al, $2013^{[66]}$ \\
\hline 7 & Root bark & Wound healer & Mittal et al, $2010^{[68]}$ \\
\hline 8 & Leaf and bark & Antibacterial & Shu et al, 2011 [69] \\
\hline 9 & Leaf and fruits & Cold and Cough & Kafle et al, $2018^{[70]}$ \\
\hline 10 & Bark & Hematological activity & Fasola et al, $2012^{[71]}$ \\
\hline
\end{tabular}

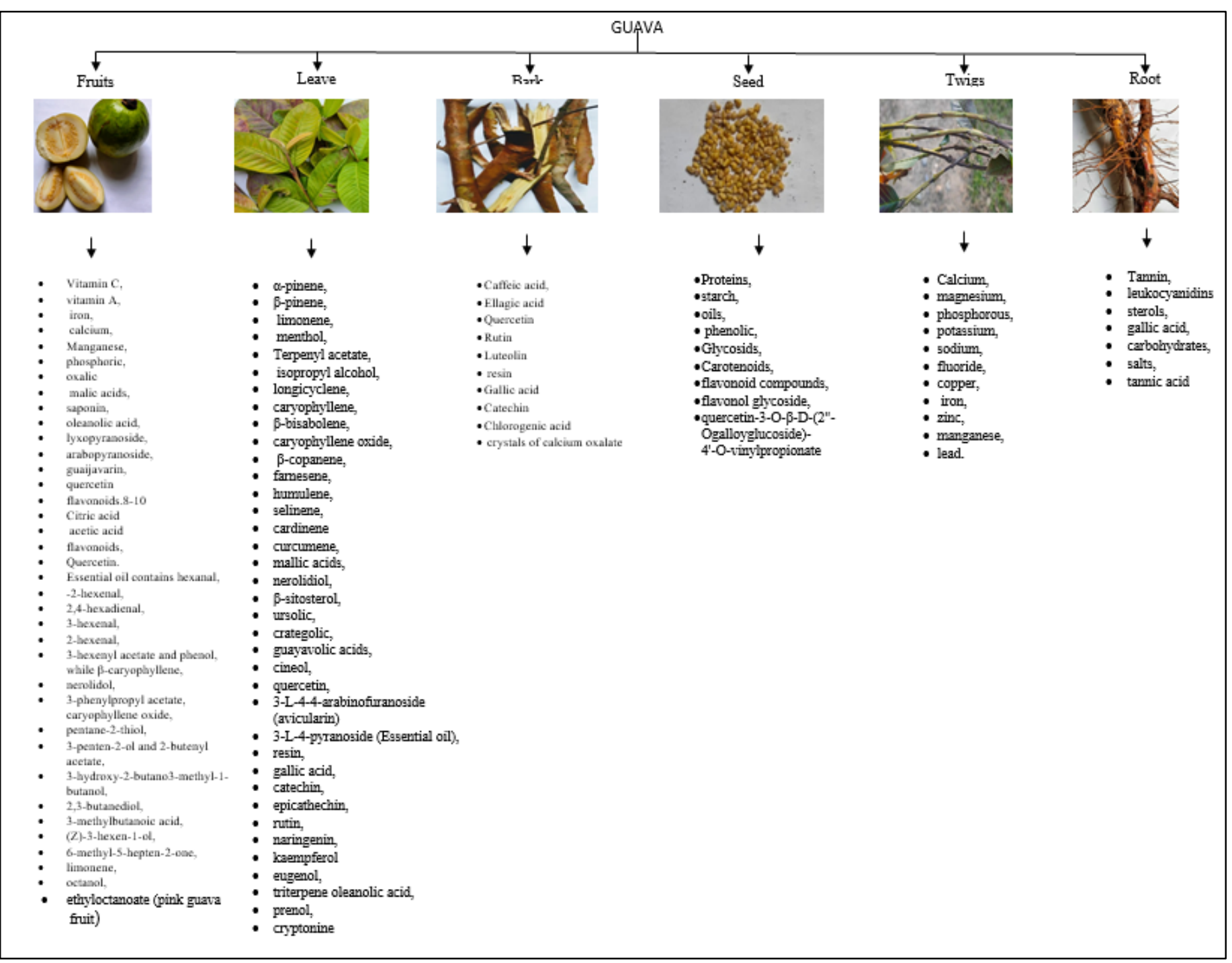

\section{Conclusion}

Guava (Psidium guajava Linn.) is well known for its food and nutritional qualities all over the world. Guavas were also included in the list of super fruits because they were high in folic acid, dietary fiber, potassium, and dietary minerals. In guava plant various bioactive compound are available like araban, arabinose, ascorbigen, destructive, guajavanoic destructive, linoleic destructive, myristic destructive, guajiverine, tannins, polyphenols, quercetin, quercitrin, ursolic destructive and terpenes. The medicinal properties of 
guava fruit, leaves, and other plant parts are also well-known in traditional medicine. Since any aspect of the guava tree has economic importance, it is grown on a commercial scale. The guava plant has gone through a critical stage as far as biological action and remedial use, and the fruit is viewed as the tropics' poor man's apple. Plant parts from the guava plant are used in a variety of consumer and medicinal products. The plant has been commonly considered for its pharmacological actions, and numerous studies as well as published literature specify its powerful anti-diarrheal, antimutagenic, hepatoprotective, antihypertensive, antioxidant, hypoglycemic, and antimicrobial properties.

\section{Reference}

1. Etim KAD, Isaac UE, Igiri AO. Morphological Alterations of the Rat Testicles Following Administration of Graded Doses of Leaves of Guava (Psidium guajava Linn.) Aqueous Extract. Tropical Health and Medical Research 2020.

2. Adhau GW, Salvi VM. Formation and quality acceptable properties of guava cheese. International Journal of Advanced Research. 2014;2(11):665-669.

3. Mitra SK, Devi HL, Chakraborty I, Pathak PK. Recent development in postharvest physiology and storage of guava. In III International Symposium on Guava and other Myrtaceae. 2012;959:89-95.

4. Jolhe P, Sahu GD, Kumar V. Preparation and evaluation of guava jelly (Psidium guajava). Journal of Pharmacognosy and Phytochemistry 2020;9(6):20612063.

5. Kafle A, Mohapatra SS, Reddy I, Chapagain M. A review on medicinal properties of Psidium guajava. Journal of Medicinal Plants 2018;6(4):44-47.

6. Upadhyay R, Dass JFP, Chauhan AK, Yadav P, Singh M, Singh RB. Guava enriched functional foods: therapeutic potentials and technological challenges. The role of functional food security in global health 2019, 365-378.

7. Sinha M, Mishra S. Effect of Value Addition on Guava Cheese with Medicinal Herbs under Ambient Storage Condition (Psidium gujava L.) cv."Allahabad Safeda". International Journal of Pure and Applied Bioscience 2017;5(3):559-566.

8. Seshadri VD, Balasubramania B, Al-Dhabi NA, Esmail GA, Arasu MV. Essential oils of Cinnamomum loureirii and Evolvulus alsinoides protect guava fruits from spoilage bacteria, fungi and insect (Pseudococcus longispinus). Industrial Crops and Products. 2020;154:112629.

9. Biswas B, Rogers K, McLaughlin F, Daniels D, Yadav A. Antimicrobial activities of leaf extracts of guava (Psidium guajava L.) on two gram-negative and grampositive bacteria. International journal of microbiology 2013.

10. Raihana AN, Marikkar JMN, Amin I, Shuhaimi M. A review on food values of selected tropical fruits' seeds. International Journal of Food Properties. 2015;18(11):2380-2392.

11. Vijaya Anand A, Velayuthaprabhu S, Rengarajan RL, Sampathkumar P, Radhakrishnan R. Bioactive Compounds of Guava (Psidium guajava L.). Bioactive Compounds in Underutilized Fruits and Nuts 2020, 503527.

12. Palachum W, Choorit W, Manurakchinakorn S, Chisti Y. Guava pulp fermentation and processing to a vitamin
B12- enriched product. Journal of Food Processing and Preservation 2020;44(8):e14566.

13. Laily N, Kusumaningtyas RW, Sukarti I, Rini MRDK. The potency of guava Psidium guajava (L.) leaves as a Functional immunostimulatory ingredient. Procedia Chemistry 2015;14:301-307.

14. Rahim N, Gomes DJ, Watanabe H, Rahman SR, Chomvarin C, Endtz HP, et al. Antibacterial activity of Psidium guajava leaf and bark against multidrug-resistant Vibrio cholerae: implication for cholera control. Japanese journal of infectious diseases 2010;63(4):271-274.

15. Upadhyay R, Dass JFP, Chauhan AK, Yadav P, Singh M, Singh RB. Guava enriched functional foods: therapeutic potentials and technological challenges. The role of functional food security in global health 2019, 365-378.

16. Ngbolua JPKTN. A review on the phytochemistry and pharmacology of Psidium guajava L.(Myrtaceae) and future direction. Phytomedicine. 2018;1(780):6919427.

17. Dinesh MR, Reddy BMC. Physiological basis of growth and fruit yield characteristics of tropical and sub-tropical fruits to temperature. Tropical Fruit Tree Species and Climate Change 2012, 45.

18. Singh SP. Guava (Psidium guajava L.). Postharvest biology and technology of tropical and subtropical fruits. 2011, 213-246e.

19. Birdi T, Krishnan GG, Kataria S, Gholkar M, Daswani P. A randomized open label efficacy clinical trial of oral guava leaf decoction in patients with acute infectious diarrhoea. Journal of Ayurveda and integrative medicine. 2020;11(2):163-172.

20. Sehrawat SK, Dhankhar SS, Pannu RK. ICAR-JRF (PGS). 2014.

21. Singh SP. Guava (Psidium guajava L.). Postharvest biology and technology of tropical and subtropical fruits. 2011, 213-246e.

22. Paull RE, Duarte O. Tropical fruits. 2012;2(Ed.2):CABI.ix + $371 \quad$ pp. http://www.cabi.org/cabebooks/ebook/20123357661 doi:10.1079/9781845937898.0000

23. Youssef M, Ibrahim R. Molecular markers associated with high Vitamin-c content in guava. Journal of Agricultural Chemistry and Biotechnology 2016;7(3):4955.

24. Bogha TT, Sawate AR, Kshirsagar RB, Bochare SS. Studies on physical, chemical and mineral evaluation of guava (Psidium Guajava L.). The Pharma Innovation Journal 2020;9(3):117-119.

25. Das AJ. Review on nutritional, medicinal and pharmacological properties of Centella asiatica (Indian pennywort). Journal of Biologically Active Products from Nature 2011;1(4):216-228.

26. Reddy OSK. Nutrition facts \& health benefits of guava fruit. Green Universe Environmental Services Society 2017.

27. Medina NNR, Herrero JVI. Guava (Psidium guajava L.) cultivars: An important source of nutrients for human health. In Nutritional composition of fruit cultivars. Academic Press. 2016, 287-315.

28. Omayio DG, Abong GO, Okoth MW, Gachuiri CK, Mwang'ombe AW. Current Status of Guava (Psidium Guajava L) Production, Utilization, Processing and Preservation in Kenya: A Review. Current Agriculture Research Journal 2019;7(3):318.

29. Vijaya Anand A, Velayuthaprabhu S, Rengarajan RL, 
Sampathkumar P, Radhakrishnan R. Bioactive Compounds of Guava (Psidium guajava L.). Bioactive Compounds in Underutilized Fruits and Nuts 2020;503527.

30. Lee S, Km YS, Choi HK, Cho SK. Determination of the volatile components in the fruits and leaves of guava plants (Psidium guajava L.) grown on Jeju Island, South Korea. Journal of Essential Oil Research 2011;23(6):5256.

31. Thome AL, Sudiana IK, Bakar A. Psidium guajava Leaves Compound As Anti-Inflammation: Systematic Review. Jurnal Natural 2019;19(3):69-71.

32. Kapoor S, Gandhi N, Tyagi SK, Kaur A, Mahajan BVC. Extraction and characterization of guava seed oil: A novel industrial byproduct. LWT 2020;132:109882.

33. Molla T, Azene H. A Systemic Review on Antioxidant and Hepatoprotective Effect of Psidium Guajava Leaf and Fruit Extract (Doctoral dissertation, Addis Ababa University) 2011.

34. Ngbolua JPKTN. A review on the phytochemistry and pharmacology of Psidium guajava L. (Myrtaceae) and future direction. Phytomedicine 2018;1(780):6919427.

35. Naseer S, Hussain S, Naeem N, Pervaiz M, Rahman M. The phytochemistry and medicinal value of Psidium guajava (guava). Clinical Phytoscience 2018;4(1):1-8.

36. Kocher GS. Status of wine production from guava (Psidium guajava L.): A traditional fruit of India. African Journal of Food Science 2011;5(16):851-860.

37. Kadam DM, Kaushik P, Kumar R. Evaluation of guava products quality. International Journal of Food Science and Nutrition Engineering 2012;2(1):7-11.

38. Rahman TU, Amanullah NT, Tahir A, Rahman AU, Khan A. Evaluation and preparation of guava jam stored at ambient temperature. Pure and Applied Biology (PAB) 2018;7(3):1064-1073.

39. Jolhe P, Sahu GD, Kumar V. Preparation and evaluation of guava jelly (Psidium guajava). Journal of Pharmacognosy and Phytochemistry 2020;9(6):20612063.

40. Kuchi VS, Gupta R, Tamang S. Standardization of recipe for preparation of guava jelly bar. Journal of crop and weed. 2014;10(2):77-81.

41. Swer Tl, Rani S, \& Bashir K. Manufacturing Of Jams, Jellies, And Marmalades From Fruits And Vegetables. Processing of Fruits and Vegetables: From Farm to Fork 2019, 59.

42. Kanwal N, Randhawa MA, Iqbal Z. A review of production, losses and processing technologies of guava. Asian Journal of Agriculture and Food Sciences. 2016;4(2).

43. Kumar M. Technology of manufacture of Guava shrikhand (Doctoral dissertation, M Sc Thesis, Centre of Food Science \& Technology, Institute of Agricultural Sciences, Banaras Hindu University, Varanasi, Uttar Pradesh, India) 2011.

44. Omayio DG, Abong GO, Okoth MW, Gachuiri CK, Mwang'ombe AW. Current Status of Guava (Psidium Guajava L) Production, Utilization, Processing and Preservation in Kenya: A Review. Current Agriculture Research Journal 2019;7(3):318.

45. Sevda SB, Rodrigues L. Fermentative behavior of Saccharomyces strains during guava (Psidium guajava $\mathrm{L}$ ) must fermentation and optimization of guava wine production. J Food Process Technol 2011;2(118):2.
46. Kaneko K, Suzuki K, Iwadate- Iwata E, Kato I, Uchida K, Onoue M. Evaluation of food-drug interaction of guava leaf tea. Phytotherapy Research 2013;27(2):299305.

47. Ponnuchamy M, Kapoor A, Pakkirisamy B, Sivaraman P, Ramasamy K. Optimization, equilibrium, kinetic and thermodynamic studies on adsorptive remediation of phenol onto natural guava leaf powder. Environmental Science and Pollution Research 2019, 1-22.

48. Uchôa-thomaz AMA, Sousa EC, Carioca JOB, Morais SMD, Lima AD, Martins CG, et al. Chemical composition, fatty acid profile and bioactive compounds of guava seeds (Psidium guajava L.). Food Science and Technology. 2014;34(3):485-492.

49. Maurya AK, Pandey RK. Influence of Guava Seed Powder Fortification on Physicochemical, Textural and Sensory Properties of Biscuits.

50. Denny C, Melo PS, Franchin M, Massarioli AP, Bergamaschi KB, de Alencar SM, Rosalen PL. Guava pomace: a new source of anti-inflammatory and analgesic bioactives. BMC complementary and alternative medicine 2013;13(1):1-7.

51. Tangirala S, Sarkar BC, Sharma HK, Kumar N. Modeling and characterization of blended guava pomace and pulse powder based rice extrudates. International Journal of Food Engineering 2012;8(1):1-24.

52. Gupta S, Veeresh Wali D, Bhoi P, Mohapaaatra P. A Survey on Guava Farming and Utilization in Kenya. International Journal of Modern Agriculture. 2020;9(3):522-529.

53. Fasola TR, Oloyede GK, Aponjolosun BS. Chemical composition, toxicity and antioxidant activities of essential oils of stem bark of Nigerian species of guava (Psidium guajava Linn.). Excli Journal 2011; 10:34.

54. Vyas N, Tailang M, Gavatia NP, Gupta BK. Antioxidant potential of Psidium guajava Linn. International Journal of PharmTech Research 2010;2(1):417-419.

55. Dakappa SS, Adhikari R, Timilsina SS, Sajjekhan S. A review on the medicinal plant Psidium guajava Linn.(Myrtaceae). Journal of Drug Delivery and Therapeutics. 2013;3(2).

56. Soman S, Rauf AA, Indira M, Rajamanickam C. Antioxidant and antiglycative potential of ethyl acetate fraction of Psidium guajava leaf extract in streptozotocininduced diabetic rats. Plant Foods for Human Nutrition. 2010;65(4):386-391.

57. Nantitanon W, Okonogi S. Comparison of antioxidant activity of compounds isolated from guava leaves and a stability study of the most active compound. Drug Discov Ther. 2012;6(1):38-43.

58. Huang CS, Yin MC, Chiu LC. Antihyperglycemic and antioxidative potential of Psidium guajava fruit in streptozotocin-induced diabetic rats. Food and Chemical Toxicology 2011;49(9):2189-2195.

59. Wang H, Du YJ, Song HC. $\alpha$-Glucosidase and $\alpha$-amylase inhibitory activities of guava leaves. Food chemistry. 2010;123(1):6-13.

60. Jang M, Jeong SW, Cho SK, Ahn KS, Lee JH, Yang DC, et al. Anti-inflammatory effects of an ethanolic extract of guava (Psidium guajava L.) leaves in vitro and in vivo. Journal of medicinal food. 2014; 17(6):678-685.

61. Lee SB, \& Park HR. Anticancer activity of guava (Psidium guajava L.) branch extracts against HT-29 human colon cancer cells. Journal of Medicinal Plants 
Research 2010;4(10):891-896.

62. Sriwilaijaroen N, Fukumoto S, Kumagai K, Hiramatsu H, Odagiri T, Tashiro M et al. Antiviral effects of Psidium guajava Linn.(guava) tea on the growth of clinical isolated H1N1 viruses: Its role in viral hemagglutination and neuraminidase inhibition. Antiviral research. 2012;94(2):139-146.

63. Gupta GK, Chahal J, Arora D. Psidium guajava Linn.: Current research and future prospects. J Pharm Res. 2011;4(1):42-46.

64. Birdi TJ, Brijes S, Daswani PG. Bactericidal effect of selected antidiarrhoeal medicinal plants on intracellular heat-stable enterotoxin-producing Escherichia coli. Indian journal of pharmaceutical sciences 2014; 76(3):229.

65. Daswani PG, Gholkar MS, Birdi TJ. Psidium guajava: A single plant for multiple health problems of rural Indian population. Pharmacognosy reviews 2017;11(22):167.

66. Lee WC, Mahmud R, Noordin R, Pillai Piaru S, Perumal $\mathrm{S}$, Ismail $\mathrm{S}$. Free radicals scavenging activity, cytotoxicity and anti-parasitic activity of essential oil of Psidium guajava L. leaves against Toxoplasma gondii. Journal of Essential Oil Bearing Plants 2013;16(1):32-38.

67. Ravi K, Divyashree P. Psidium guajava: A review on its potential as an adjunct in treating periodontal disease. Pharmacognosy reviews 2014;8(16):96.

68. Mittal P, Gupta V, Kaur G, Garg A, Singh A. Phytochemistry and pharmacological activities of Psidium guajava. IJPSR 2010;1(9):9-19.

69. Shu Y, Liu Y, Li L, Feng J, Lou B, Zhou X et al. Antibacterial activity of quercetin on oral infectious pathogens. African Journal of Microbiology Research 2011;5(30):5358-5361.

70. Kafle A, Mohapatra SS, Reddy I, Chapagain M. A review on medicinal properties of Psidium guajava. Journal of Medicinal Plants 2018;6(4):44-47.

71. Fasola TR, Oloyede GK, Bello SI. Phytochemical investigation of guava (Psidium guajava Linn.) Stem bark for haematological indices in albino swiss rats. EJEAF Che 2012;11(4):315-327. 